\title{
The Character of Papal Finance at the Turn of the Twelfth Century*
}

And so the twelfth century cannot be said to be its own epoch of papal finance, but only a time of preparation and initial development. Papal finance in its fullest sense was first known only in the thirteenth century. ${ }^{1}$

One way of construing the history of the papacy in the central Middle Ages is as an account of the ways in which the Curia responded to petitions from both lay and clerical Christians across Europe. The willingness of these petitioners to go to the pope to get their requests granted realised many of the (long-standing but hitherto formless) claims about papal supremacy which had existed for centuries. Such a view is provocative, perhaps, but not unreasonable: the importance of petitioners in advancing and elaborating papal government is well recognised. ${ }^{2}$ This article will look, with such an approach in mind, at the financial situation of the papal court-that is, income and expenditure - in the later twelfth and early thirteenth centuries.

The view of papal income advanced here is that it was dependent on petitions and requests which came to the pope. Hence income was more about people being willing to give money to Rome than about the active extraction of dues. Occasionally, of course, the papal requirement for money was such that attempts were made actively to find funds, but that was the exception rather than the rule. My approach corresponds closely with an interpretation of the papacy as a demand-driven administration: those who wanted privileges, annulments or dispensations possessed the agency in the process, in appealing to and in travelling to Rome to acquire such things. Seen in these terms, the great expansion in papal 'government' in the twelfth and thirteenth centuries was an ad hoc response to clergy and laity across Europe who wanted the papacy to legitimate their own claims to power. For example, in the twelfth century, rulers appealed to Rome for confirmation of their newly acquired royal status. That the pope

* My thanks to David d'Avray, John Sabapathy, the anonymous reviewers and the editors of the EHR for their many helpful comments, references and suggestions. All mistakes are my own.

I. 'Und so läßt sich das I2. Jahrhundert nicht als eigene Epoche der Papstfinanz ansprechen, sondern nur als eine Zeit der Vorbereitung und beginnenden Ausbildung. Eine Papstfinanz im eminenten Sinn hat erst das I3. Jahrhundert gekannt': C. Bauer, 'Die Epochen der Papstfinanz', Historische Zeitschrift, cxxxviii (1928), pp. 457-503, at 459.

2. R.W. Southern, Western Society and the Church in the Middle Ages (2nd edn., London, 1990), pp. I04-17; C. Morris, The Papal Monarchy: The Western Church from I050 to I250 (Oxford, 1989), pp. 2II-I4; T. Reuter, 'Mandate, Privilege, Court Judgement: Techniques of Rulership in the Age of Frederick Barbarossa', in his Medieval Polities and Modern Mentalities, ed. J.L. Nelson (Cambridge, 2006), pp. 413-31, at 428. On demand-driven law, see now D.L. d'Avray, 'Stages of Papal Law', Journal of the British Academy, v (2017), pp. 37-59. 
was the 'correct' legitimator for new royal titles was not a foregone conclusion: sometimes new kings did appeal to other authority figures (emperors, mainly) to confirm their status. ${ }^{3}$ However, the pope was the figure most consistently appealed to for the legitimation of regalitas. ${ }^{4}$ Alongside such petitions for legitimacy and protection came money.

There are four central points to the argument advanced here. First, papal income was mostly discretionary: to a great extent the impetus to give money to the papal court came from the willingness - and even desire- of supplicants to pay, if they got privileges or grants in return, rather than the desire of the Curia to extract. Secondly, papal income was mostly non-prescriptive: there were not many 'set' payments (fixed amounts the receipt of which was expected at regular times). This makes sense if the amount and frequency of payments were at the discretion of the payers. Thirdly, papal income was not recorded in detail. Again, this - to an extent - follows from the previous points: if there were not many set amounts, and if payments were at the discretion of the payers, then records of income would not have been needed to verify that anticipated payments of particular amounts had in fact been received. Finally, it appears that, by the end of the twelfth century, at least some papal expenditure (gifts given by the pope) was recorded in detail. This is not in contrast to the absence of records of income: if income was discretionary and hence unpredictable, then it was important to keep track of expenditure.

To make this argument, it is crucial for us to look at the extant sources for papal expenditure and income. As to income, the most significant is the II92 Liber censuum, the problematic nature of which was best described by Peter Partner: 'I do not think that anyone who has toiled through the labyrinth of the Liber censuum would cite it as one of the great achievements of human reason; it is only a particularly complicated cartulary'. ${ }^{5}$ Despite this judgement, study of the Liber has tended to dominate the existing scholarship of papal finance. The Liber-which

3. D.J. Smith, 'The Men who would be Kings: Innocent II and Spain', in J. Doran and D.J. Smith, eds., Pope Innocent II (II30-43): The World vs the City (Abingdon, 2016), pp. I8I-204, at I86-9I; B. Weiler, 'Crown-Giving and King-Making in the West, ca.Iooo-ca.I250', Viator, xli (2010), pp. 57-87; J. Watts, The Making of Polities: Europe, I300-I500 (Cambridge, 2009), p. 68. In the II4Os, both Raymond Berengar of Aragon-Catalonia and Afonso I of Portugal seem to have placed more importance on recognition by Alfonso VII, the king of Castile and self-proclaimed Imperator totius Hispaniae, than by the pope. In II 58 Vladislav of Bohemia was made a king by the emperor Frederick Barbarossa: J.B. Freed, Frederick Barbarossa: The Prince and the Myth (New Haven, CT, 20I6), pp. I70-72.

4. The king of Portugal, for example, did eventually get approval of his title from the pope, but not until Alfonso VII of Castile had ceased to be the dominant figure in Iberian politics, and only once the papal schism of II59-78 had ended: D.J. Smith, 'Alexander III and Spain', in P.D. Clarke and A.J. Duggan, eds., Pope Alexander III (II59-8I): The Art of Survival (Farnham, 20I2), pp. 203-42, at 22I-3.

5. P. Partner, The Lands of St Peter: The Papal State in the Middle Ages and the Early Renaissance (London, 1972), pp. 224-5. There might well, of course, have been a clear initial rationale for what was to be included in the Liber. But, if so, it now seems lost to us. On the question of lists and modes of thought, see J. Goody, The Domestication of the Savage Mind (Cambridge, 1977), ch. 5. I am grateful to John Sabapathy for this reference.

EHR, CXXXIII. 562 (June 2018) 
does have antecedents from earlier in the twelfth century-was composed by the papal chamberlain, Cencio, in II92. It includes a list of churches, abbeys, bishoprics and even kingdoms which were censuales - censuspayers - of the Roman Church. The 'censuses' owed by such institutions were annual dues, mostly of quite small amounts. In addition, the Liber contains details of Roman liturgies and ceremonies, papal letters and documents, oaths, and a whole melange of other records. ${ }^{6}$ Its contents are akin to the seemingly random selections found in many monastic cartularies. The census lists - the lists of those institutions which owed payments to the papacy — will be our main focus when looking at the Liber, although these lists are, as I shall show, problematic.

Beyond the Liber, there are a few records of payment of censuses and even receipts for census payments issued by the papal chamberlain or by a papal collector. Not many of these survive from the later twelfth century. There are seven receipts and records of payment from a Portuguese priory, three from a northern French monastery and one from an Italian abbey. ${ }^{7}$ These are all contemporary-or near-contemporarycopies: none of the original receipts or payment records survives. There are some further receipts issued by papal collectors surviving from the early thirteenth century, but they will not be of special interest to us here. ${ }^{8}$ All of these receipts and records of census payments were kept by those making the payments - the religious houses — and not by the papacy. Finally, we can occasionally glean information on papal income and financial records from papal letters and privileges, the formal productions of the papal chancery.

On the expenditure side, there are some surviving documents dealing with the repayment of loans and the purchase of castles and fortifications outside Rome by the pope. ${ }^{9}$ The most important source

6. Le 'Liber censuum' de l'Église Romaine, ed. Paul Fabre, L. Duchesne and G. Mollat (3 vols., Paris, I889-1952) [hereafter Liber censuum]. See T.M. Palazzi, 'Cencius camerarius et la formation du "Liber censuum", Mélanges de l'École française de Rome. Moyen-Âge, Temps modernes, xcvi (I984), pp. 49-93, at 5I, 84-6, for a summary of the contents of the Liber as they stood when it was finished in 1192 (subsequently there were a number of additions).

7. Papsturkunden in Portugal, ed. C. Erdmann (Berlin, 1927), pp. 379-80, no. I59; Papsturkunden in Frankreich, Neue Folge, III: Artois, ed. J. Ramackers (Göttingen, 1940), p. 244, no. I87; Bibliotheca Apostolica Vaticana [hereafter BAV], Vat. Lat. 579, fo. I48v, digitised at http:// digi.vatlib.it/view/MSS_Vat.lat.579. The Italian receipt has not attracted as much attention as the Portuguese and French receipts, but see Italia Pontificia, IV: Umbria, Picenum, Marsia, ed. P.F. Kehr (Berlin, I909), pp. I28-9, nos. 3-4; G. Battelli, 'I più antichi codici della badia di Fiastra', Scritti Scelti: Codici-Documenti-Archivi (Rome, 1975), pp. 419-40, at 436-7 and fig. 5.

8. Bulário Português: Inocêncio III (IIg8-I2I6), ed. A.J. da Costa and M.A.F. Marques (Coimbra, 1989), p. 355, no. 199; Bullaire de l'Église de Maguelone, I: 1030-I216, ed. J. Rouquette and A. Villemagne (Montpellier, I9II), pp. 382-3, no. 20I. For the I220s and I23Os, see N. Vincent, 'The Election of Pandulph Verracclo as Bishop of Norwich (I215)', Historical Research, lxviii (I995), pp. I43-63, at I62-3, no. 4; Urkunden- und Quellenbuch zur Geschichte der altluxemburgischen Territorien, ed. C. Wampach (II vols., Luxembourg, I935-2008), ii. 278-80, nos. 258-9.

9. Mostly edited in Emil von Ottenthal, ed., 'Documenti per la storia ecclesiastica e civile di Roma', Studi e documenti di storia e diritto, vii (I886), pp. IOI-22, 195-2I2, 317-36; R. Volpini, 'Per l'archivio pontificio tra XII e XIII secolo: I resti dell'archivio dei papi ad Anagni', Rivista di storia della chiesa in Italia, xxxvii (1983), pp. 366-405; and the Fabre-Duchesne edition of the Liber censuum. 
for expenditure which I will be discussing here, however, is the gift list at the end of the biography of Pope Innocent III (II98-I2I6). This biography - the Gesta Innocentii tertii — was written during Innocent's lifetime and in its final (probably revised) version goes up to $1208 / 9 .{ }^{10}$ The gift list includes items given by the pope and their recipients, as well as occasionally noting the purpose of the gift: Innocent gave 20 pounds for the repair of the roof of Santa Maria Maggiore in Rome, for example. Most, although not all, of the gifts have their value recorded. This is not a complete record of expenditure, but it proves that someone thought it worthwhile to record some outgoings during the first decade of Innocent's pontificate.

To a large extent, the question of how the papacy administered its income in the twelfth century is not one that has much exercised historians. The question 'how much income did the papacy have?' has been studied, somewhat inconclusively, but the nature of the papal records, and the ways in which the popes administered their income, are unresolved issues. ${ }^{11}$ Thomas Bisson, however, in his recent Crisis of the Twelfth Century, has put forward a new pan-European narrative of the development of accountancy, arguing that so-called prescriptive accountancy-itself indicative of an 'accountability of fidelity'-gave way in this period to probative accountancy. Prescriptive accounts were unchanging lists of possessions and revenue from those possessions. These lists were not updated and so the only matters at issue for the king, the lord or the pope whose property was recorded were: 'Have I received these amounts? Do I possess these lands?' The lord's vicars and provosts were only occasionally and intermittently examined on how they carried out their duties, and normally only in the form: 'Have you made sure that I received my prescribed incomes?' Probative accountancy, however, suggested accountability of office: records of income and expenditure were regularly compared to make sure the officer was managing the estate competently. For Bisson, prescriptive accounting seems to have been a precondition for probative accounting: it would not be possible to check if officers were honest (extracting and handing over the correct amounts of income) unless the expected

Io. D. Gress sub nomine D.R. Gress-Wright, 'The Gesta Innocentii III: Text, Introduction and Commentary' (Bryn Mawr College Ph.D thesis, 198I), pp. 345-5I (tr. J.M. Powell, The Deeds of Pope Innocent III by an Anonymous Author [Washington DC, 2004], pp. 257-65; Italian translation in 'Gesta' di Innocenzo III, ed. G. Barone and A. Paravicini Bagliani, tr. S. Fioramonti [Rome, 20II], pp. 274-82).

II. V. Pfaff, 'Die Einnahmen der römischen Kurie am Ende des I2. Jahrhunderts', Vierteljahrschrift für Sozial-und Wirtschaftsgeschichte, xl (1953), pp. 97-II8, at II3; P. Toubert, Les Structures du Latium médiéval: Le Latium méridional et la Sabine du IXè à la fin du XII siècle (2nd edn., 2 vols., Rome, 20I5), ii. I064-7; J. Sayers, Innocent III: Leader of Europe, II98-I2I6 (London, 1994), pp. 75-6; C. Wickham, 'The Financing of Roman City Politics, I050-II50', in P. Guglielmotti, ed., Europa e Italia: Studi in onore di Giorgio Chittolini/ Europe and Italy: Studies in Honour of Giorgio Chittolini (Florence, 20II), pp. 437-53. 
amount of income was known in advance. It was also necessary that such prescriptive records be updated if revenues changed. ${ }^{12}$ According to this interpretation, the census-books of the twelfth century papacy-most importantly the Liber censuum-constitute evidence that the papal court was mired in the prescriptive model of financial accounting; as a result, any growth of official authority, rather than affective power, in the Church in the twelfth and thirteenth centuries was not reflected in techniques of accounting. In this article, however, I will suggest that, while examining the census-books allowed Bisson to tie the papacy into pan-European trends in financial and governmental history, they are actually the wrong place to be looking if we want to understand papal finances as fully as is possible, and their wider role within papal governance.

Here, I will review the surviving evidence for papal financial administration in the second half of the twelfth and early thirteenth century, and argue that the existing distinction between 'voluntary' payments to the pope-gifts, bribes, offerings—and stipulated 'prescribed' dues - censuses, tributes - is a false dichotomy. In fact, the prescribed payments were normally as voluntary as the freely given gifts. It then follows that the overall character of papal finance was dissimilar to that of royal financial administrations in twelfthcentury Europe because it was based more on the activity and wishes of payers and petitioners and less on active extraction by a centralised administration. This had a knock-on effect on the ways in which income and expenditure were recorded. Income appears not to have been recorded in detail, probably because the papal Curia had little control over the amounts and frequency of its income; but expenditure was recorded in some detail.

Thomas Wetzstein and Stefan Weiß have both recently drawn a distinction between 'voluntary contributions' ('freiwillige Zuwendungen') to the papacy and the censuses recorded in the Liber censuum. These latter dues were those to which the papacy 'had a legal claim' and are thus distinguished from the 'voluntary contributions', which included gifts to the pope, bribes, pilgrim-offerings and so on. ${ }^{13}$ Of course 'voluntary' may not be quite the right term: if an archbishopelect wanted to receive his pallium from the pope he normally had to

I2. T.N. Bisson, The Crisis of the Twelfth Century: Power, Lordship, and the Origins of European Government (Princeton, NJ, 2009), pp. 318-40.

13. T. Wetzstein, 'Noverca omnium ecclesiarum: Der römische Universalepiskopat des Hochmittelalters im Spiegel der päpstlichen Finanzgeschichte', in J. Johrendt and H. Müller, eds., Rom und die Regionen: Studien zur Homogenisierung der lateinischen Kirche im Hochmittelalter (Berlin, 2012), pp. I3-62, at 44-54; S. Weiß, 'The Curia: Camera', in K. Sisson and A.A. Larson, eds., A Companion to the Medieval Papacy: Growth of an Ideology and Institution (Leiden, 2016), pp. $220-38$. 
provide gifts; if he did not then he would not get his pallium. But, of course, to exercise his archiepiscopal offices, he needed a pallium. ${ }^{14}$ So when we call such income voluntary it does not follow that it necessarily arose purely from the beneficence of the giver. Rather, we should see these 'voluntary' payments as 'discretionary': that is, the willingness of petitioners to pay such dues was of prime importance-the payments were not demanded or exacted by the papal court. This is different from the practice of royal officials in, for example, England, who could and would confiscate chattels if dues and debts were not paid. ${ }^{15}$ Even in England, however, the late twelfth-century Dialogue of the Exchequer drew a distinction between what happened to those who failed to pay money which they owed 'as a penalty for wrongdoing' (their goods could be confiscated) and those who 'freely [sponte] offer money [and] do not pay': the latter lost any benefits they had gained from offering the king money, but they were not obliged to pay the king the money. ${ }^{16}$ This category of gifts, offerings and so on would cover most of the income of the late twelfth-century papacy. It therefore seems entirely reasonable to see and refer to this papal income as discretionary. Indeed, I would go further: the census income should also be regarded as being discretionary, just like the rest of papal income.

The customary assumption is that the twelfth-century papal censusbooks do list income 'to which the papacy could raise a legal claim. ${ }^{17}$ Hence Bisson calls the census-books 'prescriptive' because they list prescribed - and hence expected-income. That is to say, the twelfthcentury papal census-books list the various monasteries, bishoprics, counties, duchies and kingdoms across Europe which owed an annual render (called a census) to St Peter and the pope. ${ }^{18}$ These censuses were mostly paid in return for papal protection or exemption, but

I4. On the consequences of not receiving a pallium, see S.A. Schoenig, 'The Livery of Loyalty: Innocent II and the Pallium', in Doran and Smith, eds., Pope Innocent II, pp. 3II-25, at 3I2-I3; A.J. Duggan, 'Sicut ex scriptis vestris accepimus: Innocent II and the insulae Britanniae et Hiberniae', in Doran and Smith, eds., Pope Innocent II, pp. 69-106, at 73 and n. 29; and M. Brett, 'Some New Letters of Popes Urban II and Paschal II', Journal of Ecclesiastical History, lviii (2007), pp. 75-96, at 89-94, no. 7, for an edition of the relevant decretal. For an example of an archiepiscopal delegation having trouble collecting a pallium apparently because they had not brought sufficient gifts, see K. Christensen, 'The Curious Case of Becket's Pallium: Guernes de Pont-Ste-Maxence and the Court of Alexander III', in Clarke and Duggan, eds., Pope Alexander III, pp. 243-56.

15. Magna Carta, ed. and tr. D. Carpenter (London, 2015), pp. 27, 17I-3, 216-17, 358-9.

I6. 'Dialogus de Scaccario' (The Dialogue of the Exchequer) and 'Constitutio Domus Regis' (The Disposition of the King's Household), ed. and tr. E. Amt and S.D. Church (Oxford, 2007), pp. I6I-9, I78-8I.

I7. Weiß, 'The Curia: Camera', p. 229.

I8. Chamberlain Boso kept a table de cens in the middle of the twelfth century; this was then used by Cardinal Albinus, who compiled a census list for his digesta pauperis scholaris (first recension, pre-II82; second recension, II85-9; third recension, pre-II97); Chamberlain Cencio then compiled his own census lists for the 1192 Liber censuum: T.M. Palazzi, 'Formation et carrière d'un grand personnage de la Curie au XII e siècle: Le Cardinal Albinus', Mélanges de l'École française de Rome. Moyen-Âge, Temps modernes, xcviii (1986), pp. 623-671, at 658-9; ead., 'Cencius camerarius', pp. 72-3, 88. 
some were symbolic of temporal lordship or a more generic special relationship. ${ }^{19}$

There are problems, however, both with assuming that these censusbooks are prescriptive accounts and with taking them as indicative of the overall Gestalt of papal financial administration. First, it is questionable whether the mere listing of censuses in census-books indicates that the papacy could—or even would—extract payment. Census payments were dependent on the goodwill and activity of the payer, not the papal court. Secondly, the so-called 'voluntary' contributions made up far more of the papacy's income than the censuses-and there is very little evidence that these 'voluntary' items of income had prescribed amounts in the twelfth century. The overall character of papal finance was thus one of unpredictable discretionary payments, rather than of expected regular ones.

Volkert Pfaff, the great historian of the twelfth-century papacy, used the IIg2 Liber censuum in an effort to calculate expected papal income at the end of the twelfth century. ${ }^{20}$ Pfaff's erudition is well known, but in this case his methodology has been found wanting. Pierre Toubert, in his classic tome on medieval Lazio, offered a still unmatched critique of Pfaff. ${ }^{21}$ Pfaff had based his estimations and analysis on the Liber censuum, but, according to Toubert, such census lists were not budgets or registers of income; rather, they were statements of authority, a development of the monastic cartularies which listed the properties of a particular religious house. Just because the census list named all the houses which owed a census did not mean that payment was actually made, or even expected. Further, Toubert pointed out, Pfaff took little account of income from the patrimony (probably often received in kind), for example, or of discretionary gifts or income from the papal administration (fees for privileges, letters, etc.).

Instead, if the census-books had a practical use, it may have been as much judicial as financial. In a decretal of Pope Innocent III we are told the story of how a nobleman, Matafeloni, claimed that the castellan of Palatiolum was refusing to recognise Matafeloni's rights in the fortified settlement (castrum) of Palatiolum despite these having been conceded to Matafeloni by Pope Alexander III. ${ }^{22}$ To prove his case, Matafeloni produced three pieces of evidence: the privilege of Pope Alexander which granted Matafeloni the rights of the Roman church

19. Some payments from the patrimony were clearly temporal payments owed to the papal sovereign; payments from Aragon and Portugal (and most monastic and episcopal payments) were protection censuses; the twelfth-century payments from the kingdom of Sicily have often been labelled as feudal censuses.

20. Pfaff, 'Die Einnahmen der römischen Kurie', p. II3.

2I. Toubert, Les Structures du Latium médiéval, ii. Io64-7. Weiß and Wetzstein also note the problems with Pfaff's calculations: Weiß, 'The Curia: Camera', pp. 229-30; Wetzstein, 'Noverca omnium ecclesiarum', pp. 58-9.

22. Paul Kehr was unable to identify the settlement of Palatiolum, although he placed it in Lazio: Italia Pontificia, II: Latium, ed. P. Kehr (Berlin, 1907), p. 230, no. * I. 
in Palatiolum; a census-book of the Roman church, which recorded that Palatiolum owed the papacy 40 solidi struck at the Pavia mint annually; and some witnesses who had seen the annual payment being made in times past. ${ }^{23}$ In this case, the notice, recorded in a censusbook, that a place owed a census to the papacy appears to function as proof of that place's relationship with the Holy See. The census-book does not seem to have recorded exactly what rights the papacy-and hence Matafeloni-had in Palatiolum; instead, in a pars pro toto proof, the fact that the place paid a census proved that there were rights in Palatiolum which belonged to the papacy. If the amounts of the census recorded in the census-book and the privilege were the same, which in this case they were, this must have strengthened the privilege, since it provided independent corroboration of one part of it.

We can expand on this and suggest that monasteries under papal protection might have wanted their census obligations recorded in papal census-books because they could then refer to these if they wished to prove that they had papal protection, or in order to appeal to the pope if they came under threat. If such an appeal were made by an institution which could show a past papal privilege then the two proofs of a special relationship with the pope would support each other: one-the privilege-would be a proof kept by the monastery; the other - the census-book - would be held centrally, by the papacy. ${ }^{24}$ This suggestion might account for the surprisingly low number of privileges which were copied into the papal registers. The twelfthcentury registers are lost, but Jane Sayers has pointed out that in the registers of Honorius III (I216-I227), the proportion of privileges or confirmations which were recorded is quite low. ${ }^{25}$ If religious houses knew that a record of their census was kept by the papal chamberlain, they might have been less willing to pay the extra cost to have the entire privilege registered, knowing that the census-book and their own copy of the privilege would be sufficient support in the event that they had to appeal to Rome.

A number of questions follow from this. Were the institutions recorded in the census-books expected to pay regularly every year? Did the papal court extract payments and enforce its alleged legal claims? It seems that in the second half of the twelfth century, census payments were expected when an institution petitioned for a new privilege of

23. Corpus Iuris Canonici, X 2, 26, I3, ed. Emil Friedberg (I879-8I; 2nd edn., 2 vols., Graz, 1959), ii. 386-7; Regesta Pontificum Romanorum inde ab anno post Christum natum MCXCVIII ad annum MCCCIV, ed. August Potthast (1874-5; 2nd edn., 2 vols., Graz, 1957) [hereafter Potthast], vol. i, no. I,I29.

24. H. Feigl, 'Die Registrierung der Privilegien unter Papst Innozenz III.', Mitteilungen des Instituts für Österreichische Geschichtsforschung, lxviii (1960), pp. II4-27, at I23-4.

25. J.E. Sayers, Papal Government and England during the Pontificate of Honorius III (I216-I227) (Cambridge, 1984), pp. 73-5. Of course, this explanation would not account for the privileges and confirmations which were not registered and whose recipients did not pay a census (and so were not recorded in census lists). 
protection or the reissue of an existing privilege. At this point the institution had to provide a receipt from its last payment, which it was their responsibility to keep, rather than the papacy's, and then pay the amount owed for the intervening years. Because monasteries normally wanted their protection privileges reissued by each new pope, they tended to obtain new privileges - and thus pay their census arrearsfairly frequently. It was the exempt and protected houses which actively arranged to pay the census; only rarely did the papacy attempt to collect payments. ${ }^{26}$

In the light of this logic, we might wonder whether we have misinterpreted the census payment clauses in extant papal protection privileges: 'as an indication of this liberty granted by the Roman church, you will pay one ounce of gold to us and our successors each year'; 'as an indication of this protection and liberty granted by the apostolic see, you will pay two bizantii to us and our successors each year'; 'as an indication of this liberty granted by the apostolic see, you will pay one ounce of gold to us and our successors each year'. ${ }^{27}$ These clauses seem unequivocal: payment is expected every year. And yet rather than actual payment, they probably signify that in some cases an ounce of gold was owed for every year, and in other cases two bizantii for every year. We should then read such clauses thus: 'As an indication of this liberty and protection granted by the apostolic see, for every year that passes you will pay two bizantii to us and our successors'. The Latin in such clauses is quotannis-year-by-year, yearly, annually, every year-or annis singulis or, in some older privileges, per singulos annos. ${ }^{28}$ 'You will pay an ounce of gold to us yearly' does not necessarily mean 'every year you will send us an ounce of gold'. It can also mean 'every year you will owe us an ounce of gold'. The actual frequency of transfer is not stipulated. If this is the case, then these clauses do not tell us how frequently payment was to be made, but rather how much was owed per year. It is likely that

26. B.G.E. Wiedemann, 'The Papal Camera and the Monastic Census: Evidence from Portugal, c.II50-II90', Zeitschrift für Kirchengeschichte, cxxvi (2015), pp. I8I-96.

27. There are far too many surviving protection and exemption privileges from II5O-I200 to survey here, but I have taken those from Navarre and Aragon as a representative sample; see Papsturkunden in Spanien: Vorarbeiten zur Hispania Pontificia, II: Navarra und Aragon, ed. P. Kehr (I928; 2nd edn., Göttingen, 1970), quotations at pp. 44I-5, no. III: 'ad indicium huius percepte a Romana ecclesia libertatis unam auri unciam nobis nostrisque successoribus annis singulis persolvetis'; pp. 524-6, no. I77: 'ad indicium autem huius percepte a sede apostolica protectionis et libertatis duos bizancios nobis nostrisque successoribus annis singulis persolvetis'; pp. 468-72, no. I33: 'ad indicium autem huius a sede apostolica percepte libertatis unam unciam auri nobis nostrisque successoribus annis singulis persolvetis'.

28. The three above examples all give singulis annis. Quotannis can be found in Lucii II Papae Epistolae et Privilegia, ed. J.-P. Migne, Patrologiae cursus completus, series latina (22I vols., Paris, 1844-65) [hereafter PL], vol. clxxix, cols. 830-31, no. 4; Eugenii III Pontificis Romani Epistolae et Privilegia, PL, vol. clxxx, cols. I59I-3, no. 578; Anastasii IV Romani Pontificis Epistolae et Privilegia, PL, vol. clxxxviii, cols. I004-6, no. 13. Per annos singulos: Beati Urbani II Pontificis Romani Epistolae et Privilegia, PL, vol. cli, cols. 404-6, no. I3I. Cf. also the examples in J. Johrendt, 'La protezione apostolica alla luce dei documenti pontifici (896-IO46)', Bullettino dell'Istituto Storico Italiano per il Medio Evo, cvii (2005), pp. I35-68, at I49 n. 4I. 
the payments owed were expected to mount up. Furthermore, there are indications that this was indeed the case.

Cencio, in the Liber censuum, lamented that payment could not be sent every year. ${ }^{29}$ This does, admittedly, seem to suggest that he would have liked payment every year (and was presumably bitterly disappointed on a regular basis). But Cencio's lament was probably a rhetorical expedient. There is no reason to assume what has hitherto often been taken as a given: that census payments ought to have been sent every year, but were not. In fact, there was no expectation that census payments would be sent annually. Karl Jordan pointed to the twelfth-century privileges for the abbey of St Peter on the Mount, near Metz, which made this explicit: payment should be one gold denarius per year, or one bizantius every four years. ${ }^{30}$ If the house could choose between these two options, then the frequency of payment must have been left up to them. Although only some privileges had such specific clauses - the original tenth-century founding charter for Cluny mandated payment to Rome every fifth year only-we can assume that it was acceptable for arrears to accumulate and be paid off in bulk. ${ }^{31} \mathrm{St}$ Peter of Metz perhaps wanted in writing what most other houses took for granted.

Further evidence that the frequency of payment was left up to the monasteries themselves comes from the absence of any mentions of specific dates when payments were to be made. None of the payment clauses quoted above stipulated on what day such censuses were to be paid to the Lateran palace. They could have done so: in the mid-eleventh century, Pope Nicholas II had instructed the Norman duke of Apulia and the inhabitants of Roccantica that they were to pay their annual pensiones to him on Easter Sunday. ${ }^{32}$ In the early thirteenth century, the king of England was to pay his feudal census to the pope in two instalments per year, at Easter and Michaelmas. ${ }^{33}$ The king of the Isles was to pay his census for the Isle of Man to the abbot of Furness, who acted on behalf

29. Liber censuum, i. I-5; Palazzi, 'Cencius camerarius', pp. 83-4.

30. K. Jordan, 'Zur päpstlichen Finanzgeschichte im II. und I2. Jahrhundert', Quellen und Forschungen aus italienischen Archiven und Bibliotheken, xxv (1933-4), pp. 6I-IO4, at 75, esp. n. 9; Regesta Pontificum Romanorum ab Condita Ecclesia ad Annum post Christum Natum MCXCVIII, ed. Philipp Jaffé, Wilhelm Wattenbach, Samuel Loewenfeld, Ferdinand Kaltenbrunner and Paul Ewald (2 vols., Leipzig, I885-8) [henceforth JL], nos. 8,I38 (II4I), I3,029 (II78). Jordan did, however, assume that payment was originally (in the tenth and eleventh centuries) supposed to happen 'in jedem Jahr' in general.

3I. For Cluny, see Jordan, 'Zur päpstlichen Finanzgeschichte', p. 75.

32. Das Papsttum und die Süditalienischen Normannenstaaten, I053-I2I2, ed. J. Deér (Göttingen, 1965), p. I8, no. 4 (3) (I059); Francesco Paolo Sperandio, Sabina Sagra e Profana Antica e Moderna (Rome, 1790), pp. 373-4, no. 37 (Io6I).

33. Selected Letters of Pope Innocent III Concerning England (II98-I2I6), ed. C.R. Cheney and W.H. Semple (London, 1953), pp. I77-83, no. 67 (1213-I4). Michaelmas and Easter were the two terms of the English exchequer, when sheriffs had to come and pay in the royal revenues which they had collected. Their use in King John's surrender to Pope Innocent III therefore reflects a distinctly English conception of when financial accounting should be done. 
of the pope, on the feast of the purification of the Virgin. ${ }^{34}$ The bishop of Maguelone was to pay his feudal census for the county of Mauguio to the pope at Easter. ${ }^{35}$ However, although the papal court sometimes mandated a specific day for payments from vassal kings or subjects in the papal patrimony, it hardly ever specified a payment day for the much larger number of censuses from protected or exempt monasteries. A specific time of year for payments would support the contention that they were expected to be paid once a year, every year, but there are hardly any cases when such censuses did have an appointed day for payment. This is surely because these payments were made at the discretion of the payers and there was no practical means to enforce payment.

Evidence for a discretionary view of the census can also be found in papal letters of the later twelfth century. In II63-4 Alexander III's court apparently requested that the abbey of Lagny should pay its census arrears. The abbey responded that it was not obliged to pay any census. In letters to the abbey and its diocesan bishop the pope accepted this, declaring:

Since the Roman Church has never been accustomed to demand that other churches become census-payers to her, but rather is asked [by the churches to take such a role] ... we decree that it is not allowed for us or our successors to demand the census from the church of the abbot and brothers [of the abbey of Lagny] unless it should come from their own will and pleasure. ${ }^{36}$

Here the discretionary nature of census payments was unequivocal. It is clear that, on the prompting of the abbot of Lagny, Alexander was stating the traditional custom of his predecessors: that census payments should be at the discretion of the payer and paid when they wanted, such as when a new privilege was requested.

At this point in the argument, however, we must acknowledge the relevance of so-called 'contested constructions': the way that freely given gifts could become mandatory tribute—and vice versa — processes which have been widely recognised in scholarship on gift-giving. That is to say, we need to recognise the very contingent nature of a gift: what it was and what it meant could shift depending on the needs of historical actors at any given time. So, for example, St Francis received the chapel of the Portiuncula in Assisi as a gift in I2II, but Francis insisted on paying a nominal rent every year to the monks who had given it to him, in order to deny that he was owning property. The

34. Vetera Monumenta Hibernorum et Scotorum Historiam Illustrantia, ed. Augustin Theiner (Rome, I864), p. II, no. 26 (I2I9).

35. Bullaire de l'Église de Maguelone, I, pp. 365-6, no. 198 (I2I5).

36. JL, no. I0,967 (Epistolae Pontificum Romanorum Ineditae, ed. Samuel Loewenfeld [Leipzig, I885], pp. I34-5, no. 242) (II Oct. II63-4); JL, no. II,I2I (Alexandri III Pontificis Romani Epistolae et Privilegia ordine chronologico Digesta (Anno IIS9-II8I), PL, vol. cc, cols. 333-4) (I Mar. II64-5). Cf. a letter to King Henry II in II79: 'it is not the custom of the Roman Church in any way to establish censuses, or to weigh down any church in a like manner': JL, no. I3,293 (Alexandri III ... Epistolae et Privilegia, PL, vol. cc, cols. I229-3I) (I6 Feb. II79). 
monks retaliated by giving a counter-gift to Francis every year when he presented the nominal rent, thus emphasising that Francis was giving a gift, not obligatory rent. ${ }^{37}$ In 1788 the king of Naples, Ferdinand IV, did not give the annual feudal tribute- a census and horse- to the pope which his predecessors had been giving in one form or another since I265. Instead, the king, in a private capacity, made a deposit of the monetary equivalent of the tribute, for the use of the Holy See. What was the practical difference? None, except to deny the papacy's claims of feudal overlordship over the kingdom of Naples by redefining the obligatory census as a 'voluntary, pious gift'. ${ }^{38}$ Thus the last claim of the papacy to feudal overlordship of a king came to an end when the nature of the annual payment from kingdom to papacy was changed.

There is some evidence of similar negotiations over the ways in which censuses were defined in the twelfth century. As we saw above, Cencio in his Liber censuum seemed to suggest an obligation on religious houses to pay the census every year. During his pontificate Alexander III (II59II8I) faced a financial crisis thanks to the election of a rival popeVictor IV - and his own consequent exile from Rome. Although it was only occasional and ad hoc, it is during the ir6os that we can see some active collection of papal income by Alexander's nuncios: gifts, extraordinary subsidies, procurations and, indeed, censuses. ${ }^{39}$ In II68 a letter of Alexander was dispatched which seems to suggest a conception of the census that differed from that of discretionary payments outlined above. The extant version of this letter was sent to the archbishop of Rheims, but it was probably dispatched more widely, perhaps even to every metropolitan archbishop who recognised Alexander as pope. ${ }^{40}$ Alexander asked the archbishop to compel (compello) the census-paying churches in his province to pay their owed (debitum) census arrears. ${ }^{41}$

37. G. Algazi, 'Introduction: Doing Things with Gifts', in id., V. Groebner and B. Jussen, eds., Negotiating the Gift: Pre-Modern Figurations of Exchange (Göttingen, 2003), pp. 9-27, at II for Francis. See also E. Cohen, 'Introduction', in ead. and M.B. de Jong, eds., Medieval Transformations: Texts, Power, and Gifts in Context (Leiden, 200I), pp. I-IO, at 7-9; I.N. Wood, 'The Gifts of Wearmouth and Jarrow', in W. Davies and P. Fouracre, eds., The Languages of Gift in the Early Middle Ages (Cambridge, 2010), pp. 89-1I5, at I04-5; G. Algazi, 'Some Problems with Reciprocity', Éndoxa: Series Filosóficas, xv (2002), pp. 43-50, at 46-7; A. Guery, 'Le Roi dépensier: Le Don, la contrainte, et l'origine du système financier de la monarchie française d'Ancien Régime', Annales: Économies, Sociétés, Civilisations, xxxix (1984), pp. I24I-69, at I256-9, for the overlap between gifting and tax in the medieval and early modern periods.

38. M. Schnettger, 'Das Ende der Chinea-Präsentation und der Zusammenbruch des päpstlichen Lehnswesens', Zeitenblicke, vi, no. I (2007), available at http://www.zeitenblicke. de/2007/I/schnettger (accessed 8 Mar. 20I8).

39. A. Graboïs, 'Les Séjours des papes en France au XII ${ }^{\mathrm{e}}$ siècle et leurs rapports avec le développement de la fiscalité pontificale', Revue d'histoire de l'Église de France, xlix (1963), pp. 5-I8; L. Falkenstein, 'Leistungsersuchen Alexanders III. aus dem ersten Jahrzehnt seines Pontifikats', Zeitschrift für Kirchengeschichte, cii (1991), pp. 45-75, 175-208; Wiedemann, 'Papal Camera and Monastic Census', pp. I9I-6.

40. Falkenstein, 'Leistungsersuchen Alexanders III.', p. I90.

4I. JL, no. II,697 (Alexandri III ... Epistolae et Privilegia, PL, vol. cc, col. 630, therein dated II Feb. II68-70). For a date of II68, see Falkenstein, 'Leistungsersuchen Alexanders III.', pp. I89-92. Pope Urban II had tried a similar redefinition in the late eleventh century (during an earlier schism): Wetzstein, 'Noverca omnium ecclesiarum', pp. 25-6, n. 35.

EHR, CXXXIII. 562 (June 2018) 
This injunction, while not explicitly saying the census was obligatory, is clearly moving towards such an interpretation. It is not really possible to say if this redefinition had any success: we can identify only one census probably collected in response to this circular. ${ }^{42}$ This attempted redefinition happened, however, because of the need of Alexander III's Curia for money in the II6os: it does not seem to have been a more fundamental administrative reform.

It would thus be too crude simply to claim that the papal court always wanted censuses to be seen as obligatory and payers always wanted them to be discretionary. We have seen that the II63-4 letters of Alexander III emphasised the discretionary nature of the census; in II68 a more compulsory tone was adopted. How the census was interpreted depended on the needs of the moment. One could, for instance, theorise about a situation where it was in the interests of a religious house to suggest that their census was obligatory: if a monastery was being oppressed by a neighbour and appealed for papal aid, the monastery might argue that it was obliged to pay census and in return the papacy was obliged to defend it. ${ }^{43}$

In a similar vein, different interpretations could be offered of the gifts (or payments) required to obtain papal privileges. Ian Wood has pointed out how, in a somewhat earlier period, seventh-century papal privileges for certain English foundations were dismissed by King Ecgfrith on the grounds that they had been 'bought', presumably because gifts had been offered by the petitioners. ${ }^{44}$ Doubtless in a twelfth-century world where simony - the buying of spiritual authority—was being seen in new and surprising places, emphasising that gifts and payments to the pope were freely given, and not part of a financial exchange, was a strategy to prevent similar accusations. ${ }^{45}$ Neither the papacy nor the recipient of papal legitimation would want to be tainted by the accusation of simony.

42. Falkenstein, 'Leistungsersuchen Alexanders III.', p. 190, suggests that the collection of the census from Santa Cruz in Coimbra in 1168 by Master Peter (Papsturkunden in Portugal, ed. Erdmann, pp. 379-80, no. 159) might have been in response to this circular.

43. This-hypothetical—suggestion is inspired by the situation discussed in G. Algazi, 'Feigned Reciprocities: Lords, Peasants, and the Afterlife of Late Medieval Social Strategies', in id., Groebner and Jussen, eds., Negotiating the Gift, pp. 99-I27. It is always worth remembering that reciprocity is itself a strategy (or a construction of anthropologists), not an innate quality of gifting: Algazi, 'Some Problems with Reciprocity'; M. Heim, Theories of the Gift: Hindu, Buddhist, and Jain Reflections on Dāna (Abingdon, 2004), pp. xviii, $\mathrm{xx}, 33-5,54, \mathrm{I} 44-5$. Cf. the classic work of M. Mauss, The Gift: The Form and Reason for Exchange in Archaic Societies (1925), tr. W.D. Halls (2nd edn., London, 2002), pp. 13-18, 83-5.

44. Wood, 'Gifts of Wearmouth and Jarrow', pp. I04-5; J.L. Nelson, 'Introduction', in Davies and Fouracre, eds., Languages of Gift, pp. I-I7, at II; C. Wickham, 'Conclusion', ibid., pp. 238-6I, at 240 .

45. On eleventh- and twelfth-century concerns about simony, see T. Reuter's fascinating chapter, 'Gifts and Simony', in Cohen and de Jong, eds., Medieval Transformations, pp. 157-68, at 159-63. On Reuter's suggestion that gifts from lords to monasteries probably reflected the higher status of the giver (ibid., p. I64), cf. Heim, Theories of the Gift, pp. 58-64, for a Buddhist alternative. As well as, and in conjunction with, simony, other intellectual and ideological considerations might also have contributed to a view of census payments as discretionary. The influence of academic 
At times in the twelfth century, therefore, censuses might be interpreted as obligatory, but the evidence of payment strongly points towards their discretionary character. That interpretation was made explicit in Alexander III's letters to the abbey of Lagny. The strength of the discretionary interpretation of the census, and payments to the papal court generally, needs to be recognised. The overriding feature of papal income was thus its reliance on people wanting — or rather, being willing-to pay censuses or give gifts to the papal court.

\section{II}

I mentioned above the second problem with Pfaff's estimates: that they take no account of sources of income for the papal court beyond censuses. As Weiß put it:

the Liber Censuum does not include the income offered up to St Peter's deputy voluntarily, by whomsoever and for whatever reason, and there is good reason to suppose that these 'voluntary' contributions represented a total many times greater than the monies recorded in the Liber Censuum. ${ }^{46}$

The reason why Pfaff and others have rarely discussed these other noncensus dues in detail for the twelfth century is because, on account of an almost complete absence of records, we have hardly any idea of how much these other sources contributed. There were no prescribed lists of how much a petitioner had to give to each papal official in order to get what he wanted. It is likely that the amounts and recipients of payments and gifts from litigants at the papal court were, during the twelfth and early thirteenth centuries, decided by the giver. Master Buoncompagno's Rhetorica antiqua (c.1215-26) offers a case-study of two rival bishops-elect of Magdeburg appealing to the papacy: one of the bishops-elect is told that he must give gifts of money to the pope,

Parisian theologians on royal taxation (for example, the taxation clauses in Magna Carta) has received a considerable amount of attention in recent years. The most important biblical passage for discussing taxes on the clergy (alongside the well-known 'render unto Caesar what is Caesar's') was Matthew 17.23-6, where the collectors of the temple tax asked Peter and Christ for their contributions. Christ and Peter agreed that the kings should not exact tribute (tributum vel censum) from their sons, but rather from 'others'. Nonetheless, Christ continued, in order not to scandalise the collectors, Peter was to catch a fish in whose mouth he would find a coin to pay the tax. This was a prime text from which to argue for clerical immunity from royal taxation since Christ expounded that 'the sons [of kings] should be free [from their tribute]' and exegetes could easily identify the clergy as 'sons of the celestial king'. On the other hand, Christ and Peter had, in fact, paid the tax; this passage was quite ambiguous. Any discretionary interpretations could have influenced clerical thought on papal exactions. See P. Buc, L'Ambiguïté du Livre: Prince, pouvoir, et peuple dans les commentaires de la Bible au Moyen Âge (Paris, 1994), pp. 277-8, esp. nn. II9-20; D.L. d'Avray, 'Magna Carta: Its Background in Stephen Langton's Academic Biblical Exegesis and its Episcopal Reception', Studi Medievali, 3rd ser., xxxviii (1997), pp. 423-38; Magna Carta, ed. and tr. Carpenter, pp. 258-9. My thanks to John Sabapathy for directing me towards Buc's discussion of censuses.

46. Weiß, 'The Curia: Camera', pp. 229-30; although, as I have explained above, to a large extent the census payments in the Liber censuum were 'voluntary' too. 
his brother, and various cardinals, chaplains, notaries and so on, in order for his case to be received favourably. Unfortunately, when giving instructions to his proctor and a friendly cardinal, he forgets to specify any gift for the chamberlain-and then it transpires that the other bishop-elect has spent twice as much. Unsurprisingly, our bishop-elect loses his appeal. ${ }^{47}$ Buoncompagno clearly assumed that the amounts and recipients of gifts were at the discretion of the petitioner, although naturally poor choices would not do him any good.

This discretionary rather than prescriptive character extends even to the subventions given by petitioners to officials of the papal court in their private capacity. ${ }^{48}$ According to the Gesta Innocentii tertii and the chronicle of S. Maria de Ferraria, Innocent III instituted a fixed fee (certum stipendium) for the scribes and bullatores (or the scribes and the notaries, according to the chronicle of Ferraria) payable by those who petitioned for letters. ${ }^{49}$ The obvious implication is that there were no fixed fees prior to II98. But Innocent's aim in II98 was not to introduce fixed fees per se but to strengthen the discretionary nature of contributions to the papal finances: the Gesta goes on to explain that officials of the Curia could still accept other payments provided that they were freely given. ${ }^{50}$ From a first reading of the Gesta and the Chronicle of Ferraria it might appear as if Innocent was introducing prescribed payments for the issuing of letters but in fact he was doing the opposite: by insisting that payments to officials be freely given rather than extorted, he was ensuring that the amounts offered for letters or privileges were at the discretion of the petitioner, providedpresumably - that they had paid the minimum rate (the certum stipendium). ${ }^{51} \mathrm{He}$ thus strengthened the consensual nature of papal

47. G. Barraclough, 'The Making of a Bishop in the Middle Ages: The Part of the Pope in Law and Fact', Catholic Historical Review, xix (1933), pp. 275-319, at 297-8 (summary of case); the model letters from the Rhetorica are printed at pp. 3I4-I6, nos. I-8. In general, relating to the argument of this paper, see the comments at p. 303: 'The remarkable extension of papal activity in the second half of the twelfth century, and the consequent rapid growth of the curial bureaucracy, was not attended immediately by a corresponding advance in organisation. Irregularity and the want of a fixed standard of payment was the immediate result [emphasis added]'.

48. By the mid-thirteenth century the payment to bullatores went into the camera apostolica: W.E. Lunt, Papal Revenues in the Middle Ages (2 vols., New York, 1934), i. I27-8. The fees for the scribes, however, were kept and distributed by the college of scribes: B. Schwarz, Die Organisation kurialer Schreiberkollegien von ihrer Entstehung bis zur Mitte des IS. Jahrhunderts (Tübingen, I972), pp. IO-II.

49. P. Zutshi, 'Innocent III and the Reform of the Papal Chancery', in A. Sommerlechner, ed., Innocenzo III: Urbs et Orbis (2 vols., Rome, 2003), i. 84-IOI, at 85-6. There could be an echo of the Gospel of Luke here, as there is elsewhere in the Gesta (see below). In Luke 3.I2-I3 John the Baptist ordered tax collectors not to take more than had been constituted; this was glossed in the Glossa Ordinaria with 'quibus precepit, ne ultra prescriptum exigant': BAV, Vat. Lat. I32, fo. I8v-I9r, digitised at http://digi.vatlib.it/view/MSS_Vat.lat.I32 (accessed 8 Mar. 20I8).

50. Zutshi, 'Innocent III', pp. 85-6; Deeds of Pope Innocent, tr. Powell, pp. 55-6; Gress, 'Gesta Innocentii III', p. 60.

5I. Schwarz, Die Organisation kurialer Schreiberkollegien, pp. IO-II, 25-6, theorised that there was no scale of scribal fees for different types of letters under Innocent's new rules, but that the scribal fee was now to be equal to the fee paid when the papal seal, or bulla, was applied. She supposed that there were already varying fees for bulling. 
financial administration. ${ }^{52}$ That this was Innocent's aim is confirmed by the oath sworn by the papal cubicularii, mappularii and addextratores (all papal household officers) in $1207 .{ }^{53}$ All swore that they would not exact or extort customary gifts from archbishops, bishops or abbots coming to the papal court for confirmation of their elections, but would instead accept anything which was graciously offered to them.

Innocent's institution of a fixed fee for chancery officials gives no indication that such amounts varied in accordance with what sort of letter was written. Again this suggests that the fixed fee was not really about setting prescribed amounts with some sort of financial or bureaucratic rationalisation as the aim, but rather about ensuring that papal officials were not demanding payments. The intention was that the overall amount received should be decided and offered by the petitioner. The first list of fixed fees to be paid to scribes for different types of letters comes only from the middle of the thirteenth century: 6 pence for simple letters about lands, usury, and so on; 9 pence for letters of legitimisation of birth; I2 pence for simple confirmations or protections bulled with silk; Io shillings for privileges. ${ }^{54}$ It seems likely that payments to individual papal officers for their assistance were among the most coercive elements of curial income: the individuals who received fees and tips would surely have been willing to frustrate petitions and supplications if they did not get what they felt they were owed. Doubtless that is why Innocent III explicitly tried to enforce a more discretionary approach to such payments.

The discretionary nature of most papal income (with the exception of some income from the patrimony) is the prevailing theme of the discussion thus far. One consequence of this was that the papal court could not possibly have had any precise expectations of how much payment it would receive, and in what kind..$^{55}$ The so-called 'voluntary' income was obviously unpredictable, since it depended on what the petitioners and litigants chose to give to papal officials. But even the

52. Note Zutshi's suggestion that the theology of Peter the Chanter influenced Innocent's emphasis on discretionary payments: 'Innocent III and Reform', p. 86. It seems to me, however, that Innocent's discretionary approach was closer to that of Robert of Courson, the Chanter's student: J.W. Baldwin, Masters, Princes and Merchants: The Social Views of Peter the Chanter and His Circle (2 vols., Princeton, NJ, 1970), i. I8I-3 and ii. I2I-2, nn. 49, 57-8. Either way, the importance of theology and ideology for administrative and financial reform is clear.

53. Liber censuum, i. 342-3, no. 68; A. Paravicini Bagliani, La vita quotidiana alla corte dei papi nel duecento (Rome, 1996), pp. 60-63, 106.

54. Michael Tangl, Die päpstlichen Kanzleiordnungen von I200-I500 (Innsbruck, I894), pp. 60-6I; id., 'Das Taxwesen der päpstlichen Kanzlei vom I3. bis zur Mitte des I5. Jahrhunderts', Mitteilungen des Instituts für Österreichische Geschichtsforschung, xiii (1892), pp. I-I06, at 75-6; A. Meyer, 'Eine Verordnung gegen die Korruption an der päpstlichen Kurie aus der Mitte des 13. Jahrhunderts', in B. Flug, M. Matheus and A. Rehberg, eds., Kurie und Region: Festschrift für Brigide Schwarz zum 65. Geburtstag (Stuttgart, 2005), pp. 169-73, at 171-2; Schwarz, Die Organisation kurialer Schreiberkollegien, pp. IO-II, 25-6; Lunt, Papal Revenues in the Middle Ages, i. $125-6$, ii. $497-8$.

55. Wetzstein recognised this; his subsection on 'voluntary' contributions is titled 'Unregelmäßige Einkünfte', that is, 'irregular revenue': Wetzstein, 'Noverca omnium ecclesiarum', p. 44. 
'owed' income (the censuses and tribute) was unpredictable because it, like the 'voluntary' income, was also discretionary. The greater part of papal income (both that paid to the pope and to papal officials), then, was at the discretion of the payer. Of course there are occasional suggestions of activity on the part of the papacy in gathering moneyletters from popes asking local bishops and archbishops to collect census payments-but in general papal income was contributed by the multitude of petitioners, not collected or demanded by a centralised financial administration. Many of the mandates which historians have pointed to as showing papal activity actually suggest the opposite: we can clearly see that some of these papal letters ordering the collection and payment of the census or of Peter's Pence were sent after a petitioner had offered the payment to the pope in order to get a favourable hearing. ${ }^{56}$ The request for Peter's Pence from England in the mid-twelfth century provides one such example: on 3 March IIzo Pope Innocent II ordered Abbot Hugh of Reading to collect Peter's Pence in England; on 28 March Innocent confirmed the election of Hugh to the archbishopric of Rouen, an appointment approved by King Henry I of England, whose agreement would obviously be necessary for the payment of Peter's Pence. ${ }^{57}$ This was surely a quid pro quo.

\section{III}

A corollary to the argument which sees the vast majority of payments to the papacy as discretionary is that there would have been little point in keeping a detailed record of what was received. Certainly, a simple running total might have been kept, but there would be no reason for an itemised list of income and payers. ${ }^{58}$ This fits the surviving evidence: there is very little indication that the papal court kept running registers of income and expenditure in the twelfth century. The situation thereafter

56. For one example, see Wiedemann, 'Papal Camera and Monastic Census', p. I9I.

57. In II29 Pope Honorius II had also requested that Hugh collect Peter's Pence, and both Hugh and Henry I had seemingly been eager to do so. Honorius' II29 letter sending Hugh back to England from the Curia draws an explicit link between not suspending the English bishops and the payment of Peter's Pence. Why Honorius was threatening to suspend the bishops is unknown (perhaps for earlier non-payment). See Papsturkunden in England, III: Oxford, Cambridge, kleinere Bibliotheken und Archive und Nachträge aus London, ed. W. Holtzmann (Göttingen, I952), pp. I4I, I44, I44-5, I46, I47, nos. I6, 22, 23, 25, 26; Diversorum ad Honorium Epistolae, PL, vol. clxvi, cols. I319-20, no. 3; Duggan, 'Sicut ex scriptis vestris accepimus', pp. 73-4; M. Brett, The English Church under Henry I (Oxford, 1975), pp. 48, I68-9. See C.W. Hollister and A.C. Frost, Henry I (New Haven, CT, 200I), pp. 445-7, for an interpretation which puts the papacy's financial motivations in pole position in II29-30.

58. This is analogous to the payment of the II99 crusade income tax: bishops were to send word to the pope of the summa omnium collected from their dioceses but not a detailed breakdown of who had paid how much: Potthast, vol. i, no. 922; Chronica magistri Rogeri de Hovedene, ed. William Stubbs, Rolls Series, li (4 vols., London, I868-7I), iv. I08-I2; F.A. Cazel, Jr, 'Financing the Crusades', in H.W. Hazard and N.P. Zacour, eds., A History of the Crusades, VI: The Impact of the Crusades in Europe (Madison, WI, 1989), pp. II6-49, at I35-6; W.E. Lunt, Financial Relations of the Papacy with England up to 1327 (Cambridge, MA, 1939), pp. 240-47, esp. 242. 
changed only slowly. It is possible that the papal chamberlain recorded some census payments as early as the Fourth Lateran Council in I2I5. ${ }^{59}$ Later, under Nicholas of Anagni, chamberlain of Pope Alexander IV (I254-6I) there was a-now lost-Liber receptorum: a book of receipts. ${ }^{60}$ Under Alexander IV's successor, Urban IV (I26I-4), the Camera apostolica kept its own registers of letters. ${ }^{61}$ From the 1270 we have the Rationes decimarum: estimates of the wealth of dioceses all over Europe and how much they were expected to give in crusade taxes. ${ }^{62}$ From the late thirteenth and early fourteenth centuries, full cameral account books survive- if it was not only then that they began to be kept. ${ }^{63}$

The central role played in papal financial collection and transfer by Italian merchant bankers during the later thirteenth century may further affect what kinds of records have survived from that period. ${ }^{64}$ In the later twelfth century, however, although receipts were given out for payments received, and notices were kept of some debts contracted and paid, there is no evidence of centralised accountancy: as we have seen already, receipts were apparently only kept by the payer, not the papal court. ${ }^{65}$ One exception may have been the receipt for the monastery of St Bertin for a census payment of II84. That receipt ends 'as it is written here, so was it diligently recorded in our [the papal chamberlain's] writings'. ${ }^{66}$ However, there is no indication of how it was recorded: it may have just been copied into the chamberlain's commonplace book, or even into the papal register. ${ }^{67}$ The recording

59. A papal collector's letter from I236 suggests that the Curia had a census-book which recorded a payment made at the Fourth Lateran Council, or, at least, at some time between I2I5 and I236 (the collector's figures are somewhat inconsistent). It does not appear that anyone actually intended to use this record, however: the collector initially required abbeys to present their own census receipts to him and he only looked for a centrally kept record when a particular abbey claimed it had paid at Lateran IV but did not have a receipt of its own: Urkunden- und Quellenbuch zur Geschichte der altluxemburgischen Territorien, ed. Wampach, ii. 323-4, no. 305.

6o. Heinrich Denifle, 'Die päpstlichen Registerbände des I3. Jhs. und das Inventar derselben vom J. 1339', Archiv für Litteratur- und Kirchengeschichte des Mittelalters, ii (1886), pp. I-I05, at 22, 80; P. Montaubin, 'Bastard Nepotism: Niccolò di Anagni, a Nephew of Pope Gregory IX, and Camerarius of Pope Alexander IV', in F. Andrews, C. Egger and C.M. Rousseau, eds., Pope, Church and City: Essays in Honour of Brenda M. Bolton (Leiden, 2004), pp. I29-76, at I54.

6r. Ibid., p. I54; E. Pásztor, 'I registri camerali di lettere pontificie del secolo XIII', Archivum Historiae Pontificiae, xi (1973), pp. 7-83, at 8; A. Paravicini Bagliani, Il Trono di Pietro: L'universalità del papato da Alessandro III a Bonifacio VIII (Rome, 1996), p. 72; R. Zaoral, 'The Management of Papal Collections and Long-Distance Trade in the Thirteenth Century Czech Lands', Mélanges de l'École française de Rome. Moyen-Âge, ccxxvii (2015), available at http:// mefrm.revues.org/2732 (accessed 8 Mar. 2018).

62. Lunt, Papal Revenues in the Middle Ages, i. 7I-7; id., 'A Papal Tenth Levied in the British Isles from I274 to I280', English Historical Review, xxxii (1917), pp. 49-89.

63. Paravicini Bagliani, Il Trono di Pietro, p. 72; Zaoral, 'Management of Papal Collections';

Weiß, 'The Curia: Camera', pp. 22I, 225, 232.

64. Paravicini Bagliani, Il Trono di Pietro, p. 73.

65. Wiedemann, 'Papal Camera and Monastic Census', pp. I8I-96; Weiß, 'The Curia: Camera', pp. 234-5.

66. Papsturkunden in Frankreich, III, ed. Ramackers, p. 244.

67. Although the twelfth-century papal registers are now lost, they did exist; see T.W. Smith, 'Honorius III and the Crusade: Responsive Papal Government versus the Memory of his Predecessors', in P.D. Clarke and C. Methuen, eds., The Church on its Past (Studies in Church History, 49; Woodbridge, 2013), pp. 99-109, at IOI-2.

EHR, CXXXIII. 562 (June 2018) 
practices of the payers do not give us much of an indication of how the chamberlain might have recorded this receipt: census receipts given to Santa Cruz in Portugal were copied into a cartulary; a census receipt for the abbey of Chiaravalle in the march of Ancona was copied onto the final folio of a codex of the first eighteen books of Gregory the Great's Moralia in Job. ${ }^{68}$ The very fact that the central recording of this receipt for St Bertin was explicitly stated may suggest that it was an unusual occurrence.

Further evidence for a lack of closely itemised receipts comes from the pontificate of Innocent III. When he was elected in II98, Innocent (or his new chamberlain, Brother Richard, or some other papal officer) tried to hunt down missing census payments from the king of Portugal. ${ }^{69}$ This was an unusual high point in papal activity: as I have outlined above, normally the papal court waited for census payments to come to it. The probable explanation for this change in policy is that Innocent was already aware that his plans for a crusade would require significant financial outlays: in II99 the pope requested that every bishopric in western Christendom should contribute towards the recovery of the Holy Land and ordered each bishop to instruct his inferiors to estimate and pay a fortieth of their revenue. ${ }^{70} \mathrm{We}$ are fortunate to have Innocent's letters because they give us an indication of the ways in which Innocent went about chasing down the missing payments from the Portuguese king and how it was he knew that they had not been paid. The evidence suggests that he did not have access to any records of income.

Innocent wrote to Sancho I of Portugal, reminding him that the kingdom owed two different censuses to the papacy and that neither had been paid since II79. The larger census (of two marks of gold) had

68. Papsturkunden in Portugal, ed. Erdmann, pp. 379-80, no. I59; BAV, Vat. Lat. 579, fo. I48v.

69. Wiedemann, 'Papal Camera and Monastic Census', pp. I93-4, n. 49, for Chamberlain Richard.

70. Chronica magistri Rogeri de Hovedene, ed. Stubbs, iv. Io8-I2; Cazel, 'Financing the Crusades', pp. 135-6; Lunt, Financial Relations of the Papacy with England, pp. 240-47. At the beginning of his pontificate, Innocent-according to his biographer-also secretly audited the wealth of the Roman churches in response to the demands of the Roman people to receive gifts (dona) from the pope: Gress, 'Gesta Innocentii III', pp. 4-5; Deeds of Pope Innocent, tr. Powell, p. 7. While I would not completely dismiss this passage as evidence for papal accounting, the details the biographer provides should not be taken too literally: there are undeniable textual similarities between this passage in the Gesta, and Caesar Augustus' audit of the whole world in Luke 2.I and the Glossa Ordinaria of the same: Biblia Latina cum Glossa Ordinaria (Rusch edn., Strasbourg, I480-8I; repr. in 4 vols., Turnhout, I992), vol. iv; twelfth-century MSS of Luke with the gloss: BAV, Vat. Lat. I32, fo. IIv, available at http://digi.vatlib.it/view/MSS_Vat.lat.I32, and Vat. Lat. I33, fo. Iov, http://digi.vatlib.it/view/MSS_Vat.lat.I33 (accessed 8 Mar. 20I8). Note in particular the use of describo ('audit') in both the Vulgate and Gesta; and 'ut sciret [papa] et numerum et qualitatem ipsorum [Romanorum]' (Gesta) and 'ut sciret rex numerum hominum et magnitudinem' (Glossa). As far as I am aware, none of the three suggested authors of the Gesta (see below) were particularly known for their biblical knowledge, although Giulia Barone has emphasised the author's admiration for Innocent's theological and philosophical learning: 'I Gesta Innocentii III: politica e cultura a Roma all'inizio del Duecento', in G. Barone, S. Gasparri and L. Capo, eds., Studi sul Medioevo per Girolamo Arnaldi (Rome, 20oI), pp. I-23, at 9. 
been established by Sancho's father, Afonso, in II79, in return for papal recognition of Afonso's royal title in the privilege Manifestis probatum. Innocent was able to work out that this census had not been paid since II79 from his predecessors' chancery registers, rather than from any specifically financial records. Census payments were made whenever a new privilege or a confirmation of privilege was requested; Innocent could therefore determine that the census could not have been paid since I190, when the most recent reissue of Manifestis probatum had been produced for the king of Portugal. ${ }^{71}$ From the chancery register of his predecessor, Clement III (II87-9I), Innocent further discovered that in II89-90 Sancho had told Clement's envoy, Master Michael, that he did not need to pay the census because his father, Afonso, had paid the census for ten years in $1179-80 .{ }^{72}$ However, when Innocent went back to the chancery registers of Pope Alexander III he discovered that the payment of II79-80 had been 'from devotion' and not for the census at all: it had been a gift. ${ }^{73}$ Innocent therefore sent Sancho a copy of Afonso's II79-8o letter, to prove further that, in Innocent's eyes, Afonso's payment had not been for the census. ${ }^{74}$ Innocent was thus able to calculate from the registers of papal letters rather than from formal financial records that the Portuguese kings had not paid this census since 1179 (when it had been established). In II98, therefore, we seem to be in a situation where records of income were needed, but were not yet extant.

\section{IV}

The purpose of the discussion so far has been to show that the character of papal financial administration was, at this time, dependent on the generosity and actions of those who paid, and thus fundamentally discretionary. Because papal exactions were not really prescribed-they

7I. Monumenta Henricina, ed. A.J. Dinis (I5 vols., Coimbra, 1960-74), i. 26-8, no. I2; Papsturkunden in Portugal, ed. Erdmann, pp. 342-3, no. I24.

72. For all this see Innocentii III Romani pontificis regestorum sive epistolarum, liber primus pontificatus anno I, Christi IIg8, PL, vol. ccxiv, cols. 87-8, no. 99; Bulário Português, ed. da Costa and Marques, pp. 5-6, no. 3; B.G.E. Wiedemann, 'The Kingdom of Portugal, Homage and Papal "Fiefdom" in the Second Half of the Twelfth Century', Journal of Medieval History, xli (2015), pp. 432-45, at 436-7; id., 'Papal Camera and Monastic Census', p. 193. The other census-of four ounces of gold, dating from II43-4-is stated by Innocent to have been discovered 'from the registers of our predecessor, Pope Lucius [II] of happy memory'. At the same time as claiming that the larger census (two marks) had been paid by his father in II79-80, Sancho I admitted that this smaller census had not been paid and (in II98) sent the pope 504 morabitini, the amount for the last eighteen years (there were seven morabitini to the ounce and $7 \times 4$ x I8 $=504$ ).

73. We should note here a striking example of how a discretionary gift could be reinterpreted as an obligatory payment (and vice versa), if it was required by a historical actor at the time. King Afonso, in II79, might well have thought that the census was paid 'from devotion' rather than by obligation; for Innocent in II98, however, the difference was plain. Cf. the discussion above on different constructions of the gift.

74. Innocentii III regestorum sive epistolarum liber primus, PL, vol. ccxiv, cols. 424-5, no. 448; Bulário Português, ed. da Costa and Marques, pp. 43-5, nos. 33-4.

EHR, CXXXIII. 562 (June 20I8) 
were not set amounts - the income side of papal records was thus sparse. The same, however, is not necessarily true of the expenditure side.

There is not only evidence of records of expenditure being kept during Innocent III's reign, but a partial record actually survives. It is well known: the gift list at the end of the Gesta Innocentii. ${ }^{75}$ First, there is a list of various gifts which Innocent gave to Roman and Italian churches. The various recipients are listed, and the amounts and value of the gifts are very specific:

a gilded silver pedestal ... valued at seven marks, a golden chalice, worth seventeen and a half ounces ... a golden spoon, valued at two ounces and one tarenus ... a golden chalice, worth seventeen and a half ounces ... one pair of silver basins, worth six marks ... a golden jar worth four and a quarter and a half ounces decorated all over with precious stones ... one hundred pounds and sixteen ounces of gold ... a gilded silver flask valued at six marks less four ounces ... a chalice worth seventeen and one half ounces of gold... ${ }^{76}$

The list goes on to itemise more than forty different recipients and their gifts. There is then a second list of other expenditure from the papal treasury, mainly given simply in 'pounds':

a thousand pounds of revenue he [Innocent] paid out in support of the Holy Land. A hundred pounds of revenues in gold to the nuns of Acre to buy property; a thousand silver marks for the use of the hospital of the Holy Spirit 'in Sassia', of which six hundred were in vases and forty in gold plate; for the construction of St Sixtus for the nuns, five hundred ounces of gold of the king and eleven hundred pounds of revenue... ${ }^{77}$

In addition to the recipients noted above, more than forty more are mentioned in this second section.

Clearly someone at the papal court in the first decade of Innocent's reign was keeping a detailed record of expenditure. To know so much about papal outgoings necessitated a written list; no one could have simply recalled all these outgoings and their value. ${ }^{78}$ Most-although by no means all — of the objects given away by Innocent have their value recorded. The gift list is evidence of a register of outgoings. David Gress, a recent editor of the Gesta, suggested that the gift list was 'undoubtedly compiled from cameral lists' and 'consist[ed] of copies of cameral lists of expenses and donations' ${ }^{79}$ Gress, however, also

75. On which, see B. Bolton, 'Qui fidelis est in minimo: The Importance of Innocent III's Gift List', in J.C. Moore, ed., Pope Innocent III and His World (Aldershot, 1999), pp. II3-40.

76. Deeds of Pope Innocent, tr. Powell, pp. 259-64.

77. Ibid., pp. 267-8. Powell, in his translation, gives 'fifty' ounces of gold, but the Latin is quingentas (500): Gress, 'Gesta Innocentii III', p. 353. Cf. also Deeds of Pope Innocent, tr. Powell, p. 37 ('fifty'), and Gress, 'Gesta Innocentii III', p. 37 (quingentas).

78. Cf. Deeds of Pope Innocent, tr. Powell, p. xliii: 'The ... gift list ... had to be compiled over time and with considerable care ... It has the appearance of an ongoing project, one that could easily have been extended to the end of Innocent's pontificate'.

79. Gress, 'Gesta Innocentii III', pp. 106*, II2*. 
deemed these lists to be 'rather boring' and 'of little intrinsic interest'. ${ }^{80}$ I disagree. Although it is hardly complete-not including quotidian, everyday expenses, for example - the gift list is evidence of a running record of expenditure, the earliest to survive from the papal court. ${ }^{81}$ Of course, we cannot be absolutely certain that the gift list was culled from a financial record-that is, from a record kept for the purposes of accountancy and budgeting. ${ }^{82}$ Perhaps the end purpose of keeping a register of outgoings was simply to be able to compose this gift list. ${ }^{83}$ Irrespective of purpose, however, what remains is a (partial) record of expenditure.

A comparable gift list exists for Henry III of England, from around a quarter of a century later. Nicholas Vincent and Benjamin Wild have made suggestions regarding this list, which have a bearing here. First, the English king's wardrobe carefully kept a record of the givers of gifts, as well of those to whom gifts were given. This was probably to avoid the embarrassment of regifting an object back to the person who gave it. ${ }^{84}$ While this would not be an issue for coin, it certainly would be for objects. In a similar way, it is possible that the papal court also kept a record of incomings to avoid prospective embarrassment. Like Innocent's gift list, the royal gift list recorded the weight of many of the objects received. ${ }^{85}$

Importantly, Henry III's gift list-which survives in the original manuscript - is assumed to be a record kept internally by the king's wardrobe, and used to calculate the wardrobe's rotuli de particulis. These rolls were necessary so that the exchequer could audit the wardrobe; Henry's gift list therefore had a certain, specifically financial, purpose. ${ }^{86}$ As I noted above, we cannot know whether the same is true for Innocent's gift list; it may be that records of periodic expenditure were kept purely because someone wanted to compose a gift list in

8o. Ibid., pp. по $8^{*}$, II2*.

8I. There are other gifts from the period II98-I208/9 which are not included on the gift list: Bolton, 'Innocent III's Gift List', pp. I37-9.

82. It is unclear how many different original lists were used to compile the two sections of the Gesta's gift list. However, the variation in recording practice-sometimes objects had their weight and/or value recorded ('a golden chalice worth seventeen and a half ounces'), sometimes they did not; sometimes the purpose of cash gifts was recorded ('twenty pounds for the repair of the roof'), sometimes it was not; sometimes cash gifts were described as being 'from revenue', sometimes they were not-suggests that these data were originally recorded by a number of different scribes with different priorities.

83. Cf. Deeds of Pope Innocent, tr. Powell, p. xliii: 'The inclusion of the gift list ... which had to be compiled over time and with considerable care, suggests that it was always meant to be at the end of the Gesta'.

84. N. Vincent, 'An Inventory of Gifts to King Henry III, I234-5', in D. Crook and L.J. Wilkinson, eds., The Growth of Royal Government under Henry III (Woodbridge, 20I5), pp. I2I48, at I25-7; B.L. Wild, 'A Gift Inventory from the Reign of Henry III', English Historical Review, cxxv (2010), pp. 529-69, at 537.

85. Ibid., pp. 533, 55I-69; see 555-6, 564-8 for exceptions.

86. Vincent, 'Inventory of Gifts', p. I23; Wild, 'Gift Inventory', pp. 538-40; id., 'Secrecy, Splendour and Statecraft: The Jewel Accounts of King Henry III of England, I216-72', Historical Research, lxxxiii (2010), pp. 409-30, at 410-12. 
order to showcase the pope's generosity. On the other hand, the gift list could well be evidence of the existence of a financial record comparable to the English rotuli. Such a possibility is not an absolute certainty, however.

Any records of expenditure on which the gift list was based would probably have been kept by the papal chamberlain (camerarius): he was the administrator of papal revenue from the early twelfth century onwards ${ }^{87}$ Partly for that reason, and partly because papal chamberlains are known to have composed papal biographies between II5O and I250, David Gress identified Innocent III's three chamberlains-Brother Richard (I198), Octavian of SS. Sergius and Bacchus (I200-I204) and Stephen of Fossanova (I206-I2I6) — as candidates for having written the entire Gesta, placing special emphasis on Octavian. ${ }^{88}$ Other possible authors have subsequently been suggested. ${ }^{89}$ The gift list appears to cover more than one of these chamberlains' terms of office: the silk altar cover which Innocent was recorded as giving to S. Maria of Spoleto was probably presented when the pope dedicated that Cathedral in II $98 .{ }^{90}$ A thousand-pound donation to S. Martino de Monte of Viterbo, however, can be dated to I207: this payment is mentioned in the text of the Gesta in association with other events of I207, and it was also mentioned in a privilege of Innocent III for the abbot of S. Martino dated February I207. ${ }^{91}$ Another item-a 'gold cup [worth] forty-two and a half ounces' - was given to the abbey of Fossanova 'when he [Innocent] consecrated its altar'. ${ }^{22}$ That was in $1208 .{ }^{93}$ It does

87. Jordan, 'Zur päpstlichen Finanzgeschichte', pp. 90-Io0; Toubert, Latium médiéval, ii. I063; C. Wickham, Medieval Rome: Stability and Crisis of a City, 900-II50 (Oxford, 2015), p. 248.

88. Gress, 'Gesta Innocentii III', pp. II2*-II4*. For the chamberlain as papal biographer, see A. Paravicini Bagliani, 'La storiografia pontificia del secolo XIII, prospettive di ricerca', Römische Historische Mitteilungen, xviii (1976), pp. 45-54, at 53; id., Il Trono di Pietro, pp. 80-82; Palazzi, 'Cencius camerarius', p. 80; Montaubin, 'Bastard Nepotism', pp. I54-5; B. Bolton, 'Nova familia beati Petri: Adrian IV and the Patrimony', in ead. and A.J. Duggan, eds., Adrian IV: The English Pope (Aldershot, 2003), pp. I57-79, at I6I.

89. J.M. Powell, 'Innocent III and Petrus Beneventanus: Reconstructing a Career at the Papal Curia', in Moore, ed., Pope Innocent III, pp. 5I-62, made a case for Peter of Benevento. On Powell's suggestion that Peter was the papal chaplain sent to console Queen Ingeborg in I205 (and that this explains the author of the Gesta's 'knowledge and strength of personal feeling' concerning her), see now J. Johrendt, 'Der vierte Kreuzzug, das lateinische Kaiserreich und die päpstliche Kapelle unter Innocenz III.', in M.P. Alberzoni and P. Montaubin, eds., Legati, delegati e l'impresa d'Oltremare (secoli XII-XIII)/Papal Legates, Delegates and the Crusades (I2th-I3th Century) (Turnhout, 20I4), pp. 5I-II4, at IOI-2, who identifies this chaplain as Pelegrinus. Two years after Powell, Giulia Barone made a plausible case for John, cardinal-deacon of S. Maria in Cosmedin and papal chancellor, I205-I3: 'I Gesta Innocentii III', pp. I8-2I; repeated in 'Gesta' di Innocenzo III, ed. Barone and Paravicini Bagliani, pp. I3-I6.

90. Deeds of Pope Innocent, tr. Powell, pp. 12, 264; Gress, 'Gesta Innocentii III', pp. 9, 35I.

9I. Deeds of Pope Innocent, tr. Powell, pp. 235, 267; Gress, 'Gesta Innocentii III', pp. 3I4-I5, 354; Ferdinando Ughelli, Italia Sacra siue De episcopis Italiae, et insularum adiacentium (9 vols., Rome, I644-62), i. I404 (text); see Potthast, vol. i, no. 2,997, and Les Registres de Nicolas IV: Recueil des bulles de ce pape publiées ou analysées d'après les manuscrits originaux des archives de Vatican, ed. Ernest Langlois (2 vols., Paris, I886-1905), i. 272, no. I,349, for the correct dating.

92. Deeds of Pope Innocent, tr. Powell, p. 268; Gress, 'Gesta Innocentii III', p. 355.

93. Annales Ceccanenses, ed. G. Pertz, Monumenta Germaniae Historica, Scriptores, XIX (Hanover, 1866), p. 297. 
not appear, therefore, that records of expenditure date solely to the administration of one particular chamberlain.

Many of the outgoings on the gift list were objects rather than coins, but that is not surprising: gold and silver were often kept in worked forms such as chalices. King John, Innocent's contemporary, received and dispensed income in worked forms, and in jewels. ${ }^{94}$ On the other hand, the gift list of John's son, Henry III, appears to be solely concerned with objects. ${ }^{95}$ Papal income is known to have come in forms other than coin and even other than gold or silver. The year after the battle of Las Navas de Tolosa in I2I2, the kings of Castile and Portugal and the archbishops of Toledo and Santiago sent booty captured from the Muslims to Pope Innocent III, presumably in thanks for God's aid in their victory. This comprised not just aurei Marrochinorum, oboli aurei and musimutinae, but also a pallium to cover a bed or altar and four towels (toalliolia).$^{96}$ These latter gifts were probably fabrics taken at Las Navas, embroidered with koranic verses in kufic inscriptions; perhaps the pallium was similar to the tapestry traditionally known as the 'Las Navas de Tolosa banner', but now thought to have been taken by the king of Castile in the later thirteenth century. ${ }^{97}$ If so, the pallium and towels were doubtless displayed by the pope as powerful symbols of Christian victory when, two years later at the Fourth Lateran council, a new crusade to recapture Jerusalem was proclaimed.

Income came into the papal treasury in many forms and was consequently dispensed in many forms. Even though some payments were numbered in coins, there was seemingly a degree of latitude. The monastery of St Bertin owed one ounce of gold annually but in 1174 paid 'five marks of silver, for the five ounces of gold of the next five years'. In II79 they paid two ounces of gold for two years; and in II8I they paid four unciae malachinorum for four years. ${ }^{98}$ Clearly censuses, or other payments, including those owed by subjects in the patrimony, could be paid in all sorts of currencies-silver instead of gold, for example - and probably in worked objects too. Thus the outgoings in the gift list, which are in a mixture of coin, worked gold and silver objects and precious fabrics, probably reflect the income which the papacy received. It may be instructive to note that most of Henry III's gifts were belts and cups. ${ }^{99}$ While Innocent also dispensed—and so

94. Magna Carta, ed. and tr. Carpenter, p. 396; also p. 557 nn. 87-8. See also Wild, 'Jewel Accounts of King Henry III', pp. 4I2-I3.

95. Wild, 'Gift Inventory', pp. 535, 54I ff.; Vincent, 'Inventory of Gifts', pp. I26-8.

96. Chartularium studii Bononiensis: Documenti per la storia dell'Università di Bologna dalle origini fino al secolo XV (I5 vols., Bologna, 1909-87), iii. I79-80.

97. R. Hiestand, 'Bologna als Vermittlerin im kurialen Zahlungsverkehr zu Beginn des I3. Jahrhunderts: Eine übersehene Rolle der frühen Universitäten?', Vierteljahrschrift für Sozial- und Wirtschaftsgeschichte, lxxxii (1995), pp. 332-49, at 34I; J.D. Dodds, ed., Al-Andalus: The Art of Islamic Spain (New York, 1992), pp. 326-7.

98. Papsturkunden in Frankreich, III, ed. Ramackers, p. 244; V. Pfaff, 'Der Liber Censuum von II92', Vierteljahrschrift für Sozial- und Wirtschaftsgeschichte, xliv (1957), pp. 78-96, 105-20, $220-42,325-5 \mathrm{I}$, at 329 .

99. Wild, 'Gift Inventory', pp. 535-6.

EHR, CXXXIII. 562 (June 20I8) 
probably received-many cups, he did not dispense belts, except en masse to his lay valets. ${ }^{100}$ This reinforces the suggestion that Innocent's gifts reflected the income of the papacy: in the Lateran palace, shrewd Roman merchants sold vases and cups, presumably because they were appropriate gifts for petitioners to give to the pope or papal courtiers; belts, however, must have been a specifically lay gift. ${ }^{101}$ It is likely that most of Henry III's belts were sword-belts: one surviving belt-given by Henry III to Theobald II of Champagne in I254-does not appear to have been a functioning sword-belt, however. Benjamin Wild has pointed out that a 'pendant mount' hanging below the belt would not have been able to support the weight of a two-kilogram sword and hence must have been decorative. ${ }^{102} \mathrm{He}$ is probably right, but the decorative pendant mount must have been intended to be reminiscent of a practical attachment. It is hard to think of anything else the mount could have been intended to represent. Irrespective of practicality, such an ornate gift — clearly intended to represent a sword-belt—would have been totally inappropriate to give to a pope, or for a pope to give to a church or clergyman. ${ }^{103}$

We are aware that there were cambiatores-money-changers-at the papal court in the later twelfth century. ${ }^{104}$ It could be, as Chris Wickham has suggested, that these changers, recorded across Rome since the eleventh century, actually melted down worked objects or different currencies into ingots. ${ }^{105}$ This would make them analogous to the knight silverers and smelters found in the English exchequer who checked that coins were of sufficient weight and purity. ${ }^{106}$ Another

Ioo. Pope Adrian IV apparently gave a belt to John of Salisbury in II5O-SI: A.J. Duggan, 'The Making of a Myth: Giraldus Cambrensis, Laudabiliter, and Henry II's Lordship of Ireland', Studies in Medieval and Renaissance History, 3rd ser., iv (2007), pp. 107-70, at I26 n. 89. Regarding the symbolism of gift-giving, it is clear that gifts were given with specific meanings in mind, but it is equally clear that these meanings were often lost on the recipient. See S.J. Heathcote, 'The Letter Collections Attributed to Master Transmundus, Papal Notary and Monk of Clairvaux in the Late Twelfth Century', Analecta Cisterciensia, xxi (1965), pp. 35-109, I67-238, at 222, no. I83: 'The writer thanks him [abbot G.] for a gift of some small iron chains ... although he has no idea of their significance'.

IOI. Gress, 'Gesta Innocentii III', pp. 60-6I; Deeds of Pope Innocent, tr. Powell, p. 56.

I02. B.L. Wild, 'Emblems and Enigmas: Revisiting the "Sword" Belt of Fernando de la Cerda', Journal of Medieval History, xxxvii (20II), pp. 378-96, at 379. See pp. 380, 382 for images of the belt.

103. However, Raymond de Capella, a subdeacon and nuncio of Alexander III in II77, carried not only belts but even six swords and sheaths: Codex diplomaticus regni Croatiae, Slavoniae et Dalmatiae, ed. T. Smičiklas (I8 vols., Zagreb, I904-90), ii. I46-7, no. I43. Unfortunately for him, they were stolen by pirates. Raymond's account of what the pirates took does not tell us which possessions were his and which were gifts for the pope (except for some sandals 'ad opus domini pape').

I04. Volpini, 'Per l'archivio', pp. 39I-2, no. 5 (Constantine and Maurus, cambitores, recorded in II75); ibid., pp. 392-3, no. 6 (Constantine, cambiator, recorded again in II77); Liber censuum, i. $433-8$, nos. I80-82 (Paschal, cambiator, recorded in II95); see also ibid., i. 306, no. 57 (XXXIII), for the cambiator in the list of officiales camere camerarii.

I05. Wickham, Medieval Rome, p. 175.

Io6. 'Dialogus de Scaccario', ed. Amt and Church, pp. 54-9; B. Lyon and A.E. Verhulst, Medieval Finance: A Comparison of Financial Institutions in Northwestern Europe (Providence, RI, 1967), pp. 58-60, 66-7. 
possible role of these cambiatores, however, might have been to value the various sorts of income that came into Rome. If a castrum in the papal patrimony sent three gilt tapestries and a couple of chalices, but their annual pensio was a particular amount of the money of Lucca, someone needed to work out how much they had paid. Because the papal expenditure in the gift list is given in cash and worked goods, it seems unlikely that all income was melted down into ingots (and this would not work for fabrics, obviously), so it is possible that cambiatores were, in some measure, valuers. ${ }^{107}$ The problem potential valuers faced was that while it was possible to value worked objects by their weight - the papal chamberlain Jordan is recorded as having weighed the value of gifts to the pope in the early II5Os-it would have been relatively difficult to value items such as jewels or fabrics. ${ }^{108}$ The variation in monetisation across Europe meant that some petitioners would have been more able than others to pay in cash as opposed to worked goods or other objects and, even among those who paid in cash, the relative supplies of gold and silver across Europe would have led to variation in how income was received. Such variation might have militated further against prescriptive accounting: why prescribe set amounts when the form in which you will receive income is totally beyond your control? But this need not imply a laissez-faire attitude at the point of receipt itself. Vincent, studying Henry III's gift list, posited that objects were marked when they came into the king's possession, so that their future course could be easily followed. ${ }^{109}$ If the same was done at the papal court, then it doubtless went hand in hand with a record of value, so that one could compare the mark on an object with a written record and check the value given it by the cambiatores.

\section{V}

The rub: how much money did the papacy actually have? To use the sums in the gift list in an attempt to reconstruct papal outgoings would be futile. As I noted above, these sums cannot even be close to total outgoings. Some tentative arguments can made though. The sums recorded are considerable: 926.25 ounces of gold; 9,265 ounces of silver; 4,996 pounds (mostly 'of revenue': proventus), plus another I,I3O Sienese pounds of revenue. This does not include the 6,000 pounds which is not itemised, but merely stated to be 'for the marriages of widows and orphans', for giving valets their military belts, and giving 'alms to orphans and widows, to the poor and infirm ... to domestics

I07. Cf. Paravicini Bagliani, Il Trono di Pietro, p. 73.

I08. Not that Chamberlain Jordan was weighing the gifts fairly, according to John of Salisbury:

I.S. Robinson, The Papacy, I073-II98: Continuity and Innovation (Cambridge, 1990), p. 254. I09. Vincent, 'Inventory of Gifts', p. I23. 
and neighbours, both clerical and lay'. ${ }^{110}$ These are just the objects and sums whose value is recorded; there are some other gifts whose value is not recorded. While these outgoings probably cover only about ten years (II98-I208/9), nonetheless they put the estimates of papal income calculated by Volkert Pfaff from the Liber censuum in a different light. Pfaff calculated that income would have been around I,2I4 ounces of gold a year, and that includes the many censuses which were certainly not paid every year, but every few years. As Pierre Toubert noted, Pfaff's estimates calculate the income from sources which the papal court could not always count on (censuses) and do not include what was probably more regular income from the patrimony. ${ }^{111}$ Furthermore, there was income from letter-production, from pilgrim offerings and so on. While Toubert's objections are undeniable, and have been taken on board, Pfaff's calculations, while incomplete, still often appear as the closest approximation of papal income possible. ${ }^{112}$ Looking at the income from the gift list, however, we cannot but realise that the pope was considerably more financially secure than Pfaff's estimates, based on the II92 Liber censuum, would suggest. ${ }^{113}$

The four aspects of papal finance outlined here-that income was mostly discretionary; that income was mostly non-prescriptive; that income was not recorded in detail; that expenditure was recorded in some detail-were obviously interrelated. It was the cumulative effect of all of them which gave papal finance its character. An income based on discretionary payments might still produce detailed records of income if it is prescriptive: if there are pre-set amounts of expected income, then it makes sense to record what actually comes in and check if the two match up. It is the lack of prescriptive income which removes any need for records of actual income. Further, an inability to predict how much income will be received means that it is more important to record expenditure: when we have no control over what we receive, it makes controlling what we spend all the more imperative.

We cannot know whether Innocent or his chamberlains were the first to introduce records of expenditure, such as the gift list of II98I208/9, or whether similar records were kept by chamberlains of the

IIo. For cash gifts only, see Bolton, 'Innocent III's Gift List', p. II6. Innocent also gave 200 solidi, Ioo massemutinas, 32 gold obols and I tari which are not included in my numbers. There were also some gifts and payments recorded in the text of the Gesta which I have not included. I have calculated the totals from Gress, 'Gesta Innocentii III', pp. 345-55, with one reading (duarum for quarum) taken from the Migne edition (Gesta Innocentii III, PL, vol. ccxiv, col. ccviia) and noted by Powell: Deeds of Pope Innocent, p. 272. There are one or two omissions in Powell's translation of this section.

III. Pfaff, 'Die Einnahmen der römischen Kurie', p. II3; Toubert, Latium médiéval, ii. Io64-7. As Toubert emphasises, there is also the problem of conversion rates: ibid., ii. I065-6. Weiß also notes the problems with Pfaff: 'The Curia: Camera', pp. 229-30.

II2. Robinson, Papacy, pp. 280-82; Sayers, Innocent III, pp. 75-6; but cf. Morris, Papal Monarchy, pp. 215-17.

II3. Although cf. King John's annual English income: between 1199 and I202, circa £24,000; between I2O7 and I2I2, £49,000 (min.): Magna Carta, ed. and tr. Carpenter, p. 207. 
later twelfth-century popes. However, Innocent's apparent inability to consult records of income while hunting down the missing Portuguese royal census shows that records of income were certainly not kept before Innocent's pontificate (and probably not during it either, given that only one denominated payment to the pope is mentioned in the Gesta). ${ }^{114}$ Innocent's gift list tells us a great deal about papal finance-far more than the census-books to which so much attention has been directed. What is certain about papal financial administration is that records of income were almost totally non-existent during this period. This is not because the papal court was less advanced than, say, the English exchequer or even the Scottish royal chamber. Because papal wealth depended on the will of the payer to a much greater extent than was the case for the English or Scottish king, there were few set payments which could be expected every year. For this reason there was little point keeping a record of how much had been paid by each payer. Nor would there have been much point in holding papal officials to account with regard to money coming in. The official to whom money was given could simply tell the accountants that he had only received half the amount he actually had while pocketing the rest. Without normative, prescriptive fees there was no way of checking whether income was being embezzled. Papal income was different from royal income in England, or other lordships, because it depended to a much greater degree on the propria voluntas of the payers. ${ }^{115}$

If Innocent and his chamberlains were the first to begin keeping records of expenditure, did they also begin keeping records of income too? There is no reason to think so. We need not expect records of income and of expenditure to go hand in hand. The two appear to have been independent. We have evidence that expenditure was being recorded by $1198-1208 / 9$, when the gift list was compiled. It is possible that there was some form of probative accounting session for expenditure, as there was, apparently, for the expenditure of the crusading income tax in or after $1218 .{ }^{116}$ In support of this assumption,

II4. Deeds of Pope Innocent, tr. Powell, p. I7; cf. ibid., pp. 24-5, 60, where Innocent was promised money, and was given some silver cups.

II5. I have not here commented on the possibility that the proposed financial reforms of II97, I2I5 and I225-by which the Curia was to receive a benefice in every cathedral (II97) or a tithe of each cathedral's revenue (I215) or two benefices in every cathedral (I225)-were intended to replace voluntary subventions with prescribed fees and perhaps even enforceable collection. The I2I5 reform especially presupposes that the total income of each cathedral is known and a specific amount (one-tenth) be put aside for the papacy. Would this income have been actively extracted through collection and sanctions? Since none of these reforms got off the ground it is impossible to know for certain what they represent. It is also worth noting that the impetus for the original II97 proposal came from Emperor Henry VI, not the Curia. R. Kay, 'Gerald of Wales and the Fourth Lateran Council', Viator, xxix (1998), pp. 79-93; id., The Council of Bourges, I225: A Documentary History (Aldershot, 2002), pp. I86-99.

II6. Onorio III e la Sardegna (I2I6-I227), ed. M.G. Sanna (Cagliari, 20I3), pp. 20-23, no. IO: ‘... iidemque distributores ipsi legato et magistris Hospitalis et Templi reddant diligentissime rationem ... et tam testimoniales littere super quantitate pecunie comisse distributoribus ipsis, quam scriptura ratiocinii quod cardinali et magistris reddiderint antedictis diligentissime, conserventur...'. This is one of several tentative indications that the crusade tax of I2I5-I8 might have involved a somewhat more organised collection and distribution system than had hitherto existed.

EHR, CXXXIII. 562 (June 2018) 
we could turn (rather mischievously) to Innocent III's sermon 26. While expounding the parable of the 'shrewd manager', Innocent explained how officials should render account (reddere rationem): 'calculation [computatio] must be made, as through that ... it should be known and should appear what is left [residuum] and what spent [distractum]'. ${ }^{117}$ Innocent does not mention income in his description of holding officers to account; his conception of computatio allowed only for total and expenditure.

Innocent and his predecessors depended on their petitioners, their litigants, their pilgrims, abbots, bishops and archbishops for money. It was not the steward's fault if people were less generous one year than the next, and there was no consistently effective way of, nor much legal justification for, trying to enforce payment. The discretionary nature of most papal income militated against prescribing set amounts for fees or gifts and removed any pressing need to record exactly how much each payer had paid. On the other hand, the officials of the papal court had full control over expenditure and so they kept a close eye on what they spent, and what they had left.

The nature of papal administration was shaped by the desire for papal approval. This meant that income was, in turn, dependent on there being demand for papal legitimation. In some situations, such as a papal schism, this was a problem. When there were two opposing popes, demand for papal legitimation must have dropped because there was no longer certainty that everyone would respect a privilege or grant which was approved only by one of the possible popes. Indeed, papal privileges might have been a hindrance in such a situation, since a possible opponent of the recipient would have a ready-made excuse for denying the legitimacy of a grant given by the 'wrong' pope. When demand for papal approval dropped, the income of popes must have dropped too. That is why Pope Alexander III was so desperate for cash in the II6os. His attempts to extract money must have alienated a great many churchmen who expected payments to the Curia to require their own agency and approval. Alexander might therefore have damaged the willingness of petitioners to appeal to him, but his more immediate concern was to combat the imperially backed antipopes. If he lost that battle then the long-term future of papal authority would not really affect him. Actively collecting money was a necessarily short-termist action.

Popes were powerful because they had, if not a monopoly, then at least a strong hold over various different sorts of grants: marriage dispensations, exemptions from episcopal control, crown-givings and so

II7. Innocentii papae huius nominis tertii sermones de tempore, sermo 26, PL, vol. ccxvii, cols. 427-34: 'quid sit residuum, quidve distractum'. Cf. Cicero, On the Agrarian Law, 2.59, tr. Charles Duke Yonge, The Orations of Marcus Tullius Cicero (4 vols., London, I85I-86): 'what return he has made, and what he has left' ('quid relatum, quid residuum sit'), available at http://data. perseus.org/citations/urn:cts:latinLit:phio474.phioII.perseus-engI:2.59 (accessed 8 Mar. 20I8). 
on. Papal government was premised on that. When-or if-petitioners stopped believing that the pope was the person to go to in order to get those grants, then the pope ceased to be powerful, and, indeed, rich. The reach of papal government- that is, the judgements and income of the Curia-shrivelled. But when Christians across Europe looked to the pope for all such grants and rights, then papal authority could be unmatched.

Institute of Historical Research, London BENEDICT G.E. WIEDEMANN 